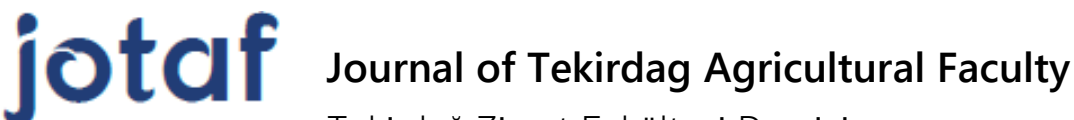 \\ Tekirdağ Ziraat Fakültesi Dergisi
}

\section{Determination of Physicochemical Properties and Antioxidant Capacity of Artichoke (Cynara cardunculus var. Scolymus L.) Jam Produced from Different Cultivars}

\author{
Farklı Çeşitlerden Üretilen Enginar (Cynara cardunculus var. Scolymus L.) Reçellerinin \\ Fizikokimyasal Özellikleri ve Antioksidan Kapasitesinin Belirlenmesi
}

\section{Feride DURMUS ${ }^{1}$, Gulsah OZCAN-SINIR ${ }^{1}$, Kubra Gizem SAHIN ${ }^{1}$, Omer Utku ÇOPUR $^{1 *}$}

\begin{abstract}
Artichoke jam was prepared from three cultivars; 'Bayrampaşa', 'Sakız' and 'Imported' (Cypriot). Jams were analyzed for physicochemical properties (total dry matter, total soluble solids ( ${ }^{\circ} \mathrm{Brix}$ ), $\mathrm{pH}$, total acidity, reducing sugars (\%), total sugars (\%), hydroxymethylfurfural, ascorbic acid and colour), antioxidant capacity (DPPH, FRAP, CUPRAC), total phenolic content and sensory properties (color, appearance, odor, taste, consistency and overall acceptability). Water-soluble dry matter and total dry matter contents of artichoke jams were determined between $69.75-70.80 \mathrm{~g} / 100 \mathrm{~g}$ and $73.36-74.36 \mathrm{~g} / 100 \mathrm{~g}$, respectively. As a result of the colour analysis, it was observed that $\mathrm{L}$ values were decreased, a values were increased and $\mathrm{b}$ values had no significant changes in all samples after the jam-making process. Results of the antioxidant capacity methods were $10.21-22.99 \mu \mathrm{mol}$ Trolox/g dry weight in CUPRAC method, $7.41-7.67 \mu \mathrm{mol}$ Trolox/g dry weight in DPPH method and $6.47-14.12 \mu \mathrm{mol}$ Trolox / g dry weight range in FRAP method, respectively. 'Bayrampaşa' sample showed the highest total antioxidant activity according to FRAP and CUPRAC methods and also it had the highest total phenolic content $(183.36 \mathrm{mg}$ GAE/100 g). In addition, sensory analyzes including colour, odour, taste, consistency and appearance characteristics of the jam samples were performed using "Hedonic Test" method and jam made with 'Imported' sample was determined as the most preferred sample. Consequently, the industry should consider using 'Bayrampaşa' cultivar for jam production because of its antioxidant activity as well as 'Imported' cultivar had better sensorial properties it can also be contemplated.
\end{abstract}

Key words: Artichoke (Cynaracardunculus var. scolymus L.), jam, antioxidant capacity, total phenolic content, color

\section{$\ddot{O}_{z}$}

Bu çalışmada 'Bayrampaşa', 'Sakız' ve 'İthal' (Kıbrıs) olmak üzere üç farklı enginar çeşidinden enginar reçelleri üretilmiş ve reçel örnekleri fizikokimyasal özellikler (toplam kuru madde, suda çözünür kuru madde ( ${ }^{\circ}$ Briks), $\mathrm{pH}$, toplam asitlik, indirgen şeker (\%), toplam şeker (\%), hydroxymethylfurfural, askorbik asit ve renk), antioksidan kapasitesi (DPPH, FRAP, CUPRAC), toplam fenolik bileşik içeriği ve duyusal özellikler (renk, görünüş, koku, tat, kıvam ve genel kabul edilebilirlik) bakımından incelenmiştir. Enginar reçellerinde suda çözünür kuru madde miktarlarının 69.75 ile $70.8 \mathrm{~g} / 100 \mathrm{~g}$, toplam kuru madde miktarlarının ise 73.36 ile $74.36 \mathrm{~g} / 100 \mathrm{~g}$ arasında değiştiği 1*Sorumlu Yazar/Corresponding Author: Omer Utku COPUR, Uludag University, Faculty of Agriculture, Department of Food Engineering, 16059, Nilüfer,

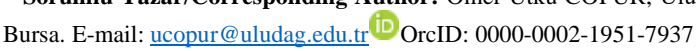

Feride DURMUS, Uludag University, Faculty of Agriculture, Department of Food Engineering, 16059, Nilüfer, Bursa. E-mail: feridedurmus@ gmail.com 0000-0002-6431-1428

Gulsah OZCAN-SINIR, Uludag University, Faculty of Agriculture, Department of Food Engineering, 16059, Nilüfer, Bursa. E-mail: gulsahozcan@uludag.edu.tr (iD) OrcID: 0000-0003-3954-0058

Kubra Gizem SAHIN, Uludag University, Faculty of Agriculture, Department of Food Engineering, 16059, Nilüfer, Bursa. E-mail: k.gizem.sahin@ @otmail.com (D) OrcID: 0000-0003-0298-0615

Attf/Citation: Durmus, F, Ozcan-Sinir, G, Sahin, K G, Çopur, O U. 2020. Determination of physicochemical properties and antioxidant capacity of artichoke (Cynara carduncuus var Scolymus L.) jam produced from different cultivars. Tekirdağ Ziraat Fakültesi Dergisi, 17(2), 191-202.

*Bu çalışma Yüksek Lisans tezinden hazırlanmıştır.

CBu çalışma Tekirdağ Namık Kemal Üniversitesi tarafindan Creative Commons Lisansı (https://creativecommons.org/licenses/by-nc/4.0/) kapsamında yayınlanmıştır. Tekirdağ 2019 
Durmus \&Ozcan-Sinir\& Sahin \&Copur Determination of physicochemical properties and antioxidant capacity of artichoke (Cynara carduncuus var Scolymus L.) jam pro duced from different cultivars belirlenmiştir. Renk analizleri sonucunda reçele işleme sırasında hammadde ile kıyaslandığında reçel örneklerinin $L$ değerlerinin azaldığı, $a$ değerlerinin artış gösterdiği ve $b$ değerlerinde ise önemli bir değişiklik olmadığ saptanmıştır. Antioksidan kapasite tayin yöntemlerinden elde edilen sonuçlar sırasıyla CUPRAC yönteminde $10.21-22.99 \mu \mathrm{mol}$ troloks/g kuru ağırlık, DPPH yönteminde $7.41-7.67 \mu$ mol troloks/g kuru ağırlık, FRAP yönteminde ise $6.47-14.12 \mu \mathrm{mol}$ troloks/g kuru ağırlık aralığında değişiklik göstermiştir. CUPRAC ve FRAP yöntemlerine göre en yüksek antioksidan aktiviteye sahip örneğin Bayrampaşa enginarından üretilen reçel örneği olduğu gözlemlenmiştir. Toplam fenolik bileşik içeriği bakımından da yine Bayrampaşa enginarından üretilen reçellerin (183.36 mg GAE/100 g) daha yüksek değerlere sahip olduğu tespit edilmiştir. Duyusal analiz işleminin gerçekleştirilmesinde "Hedonik Test" yöntemi kullanılmıştır. Yapılan istatistiksel değerlendirmeler sonucunda kıvam bakımından Bayrampaşa örneğinin daha çok tercih edildiği belirlenmiştir. Renk, görünüş ve genel kabul edilirlik bakımından ise 'İthal' enginardan üretilen reçel örneğinin diğer reçel örneklerine kıyasla daha yüksek oranda tercih edildiği saptanmıştır. Araştırma sonuçları hem nütrasotik hem de tüketici tercihleri açısından değerlendirildiğinde enginarın reçele işlenmesinin piyasaya yeni bir ürün kazandırmak amacıyla uygun olacağı belirlenmiştir.

Anahtar kelimeler: Enginar (Cynaracardunculus var. scolymus L.), reçel, antioksidan kapasitesi, toplam fenolik bileşen, renk 
Artichoke (Cynara cardunculus var. scolymus L.) is a vegetable from Asteraceae family with the Mediterranean origin, which has good sensory characteristics (flavour, taste, smell, etc.) and rich in nutrients. It contains $86.5 \%$ water, $2.3-3 \%$ protein, $0.2-0.3 \%$ lipid, and $7.8 \%$ carbohydrate, and several minerals $(\mathrm{K}, \mathrm{P}$, $\mathrm{Fe}, \mathrm{Na}$, and Ca), vitamins (A, B1, B2, B6, and C) and phenolic compounds (Lattanzio et al., 2009, Eser, 2002). The artichoke plant is cultivated for its head (flower) which is rich in bioactive phenolic compounds, inulin, fibre and minerals. In addition, the leaves of artichoke also contain a significant amount of phenolic compounds (chlorogenic acid, 1,5- and 3,4-di-caffeoylquinic acids, and cynarin) and therefore have been used for herbal therapy as a choleretic, diuretic, liver-protective and fat-reducing agent since ancient times (Lattanzio et al., 2009). It was proven with many pharmacological studies that in addition to its hepatoprotective, anticarcinogenic, antioxidant, antibacterial, anti-HIV activities, artichoke extract is effective in removing bile fluid from the liver and reducing cholesterol biosynthesis and LDL oxidation (Wang et al., 2003; Ciancolini et al., 2013).

Globe artichoke has a wide place especially in agricultural areas of Mediterranean countries. It is mostly produced in Italy (365.991 tonnes), Egypt (236.314 tonnes), Spain (185.801 tonnes), China (85.532 tonnes) and France (45.914 tonnes). As well as it is grown in ear-east countries like Turkey and Iran, Northern Africa region (such as Morocco, Algeria, Tunisia) and South America (FAO, 2018). Bayrampaşa and Sakız cultivars are widely grown in Turkey since artichoke production is carried out by vegetative methods. Also, native and imported (Cypriot) artichoke cultivars are consumed as canned or frozen. Izmir (11.845 tonnes/year), Bursa (5.724 tonnes/year), Aydın (6.291 tonnes/year) and Sakarya (6.217 tonnes/year) are most popular cities for artichoke production because of their suitable climate (TUIK, 2018).

Nowadays increase in demand for food in parallel with the increase in the population, preservation and storage of food, and extension in shelf life are an important issue for consumers. Because long-term storage of fruit and vegetables is difficult, they can be preserved by using various techniques (cold storage, freezing, canning, processing into jam etc.). As a result of the high respiration rate of artichoke plant after harvesting, it is subjected to a rapid loss of weight and nutrients with mechanical, biochemical, physiological and microbial degradation. For this reason, studies on artichoke were mainly focused on extending its shelf life. One of the conservation methods used for this aim is jam making. The main purpose of this method is to prevent microbial activities by decreasing the water activity of artichoke (Shinvari and Rao, 2018; Wolf, 2016, Muratore et al., 2015). Foods that have high sugar content such as jam and marmalade, keeps the water activity around 0.8. By this way, spoilage caused by osmophilic and osmotolerant microorganisms is substantially prevented (Cemeroğlu et al. 2001). Sakız, Bayrampaşa and imported (Cypriot) cultivars were chosen for jam production in the present study since they are most consumed cultivars in Turkey.

The objective of the present study was to produce artichoke jam from three different cultivars (Bayrampaşa, Sakız, and Cypriot) and compare their physicochemical properties, antioxidant capacity and total phenolic content as well as their sensorial acceptance. 


\section{Materials and Methods}

\section{Material}

Bayrampaşa (BP) and Sakız (S) artichokes used in the research were procured as fresh in harvest period from manufacturers in Bursa and Aydın provinces, vacuum-packed, and stored at $-18^{\circ} \mathrm{C}$ until processed into jam. The import (I) artichoke was purchased from a local market as peeled, cleaned and frozen. The artichoke hearts were smooth round tray shaped (average diameter between 7-12 cm) and were processed into jam before browning occurred due to polyphenol oxidase enzyme.

\section{Jam Production}

Artichoke hearts were cut into $1 \times 1 \mathrm{~cm}$ cubes and kept in $0.2 \%$ citric acid solution until jam production in order to prevent enzymatic activity, then they rinsed with drinking water to cleanse from residual citric acid.

Sugar, cinnamon sticks, clove and drinking water were added on chopped artichoke cubes placed in open stainless steel kettle and cooked without stirring. In the formulation, $350 \mathrm{~g}$ of artichoke heads, $350 \mathrm{~g}$ of sugar, $2 \mathrm{~g}$ of cinnamon sticks, $0.1 \mathrm{~g}$ of clove, $0.8 \mathrm{~g}$ of citric acid and $297.1 \mathrm{~g}$ of drinking water were used for the production of $1 \mathrm{~kg}$ of jam. After boiling started, Brix was checked at certain intervals and citric acid was added when the Brix reached $72^{\circ}$ (Tamer, 2011). After this process, jams were cooked for 5 more minutes and rapidly cooled to $80-85^{\circ} \mathrm{C}$ for filling. After filling into glass jars, lids were tightly closed and pasteurization was carried on $98^{\circ} \mathrm{C}$ for 15 minutes (Jawaheer et al., 2003). Jam samples were produced with 3 parallels and 3 jars for every parallel of each cultivar (BP, I, and S).

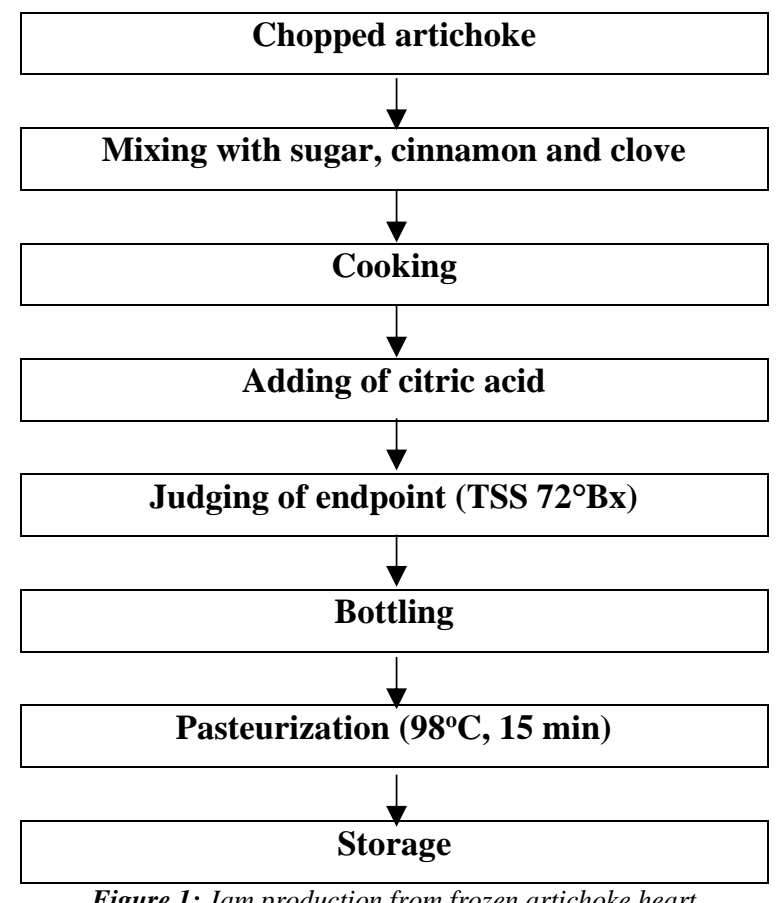

Figure 1: Jam production from frozen artichoke heart 
Analyzes of Jam

Analyzes were applied on jam samples as 3 parallels for every sample (BP, I, and S).

Raw materials (frozen artichokes) were subjected to moisture, ascorbic acid, colour ( $L, a, b)$, antioxidant capacity (DPPH, FRAP, and CUPRAC), and total phenolic content analysis. Artichoke jams were subjected to water-soluble dry matter (Brix), total acidity, $\mathrm{pH}$, ascorbic acid, colour $(L, a, b)$, antioxidant capacity (DPPH, FRAP, and CUPRAC), and total phenolic content analyzes. Sensorial analysis (hedonic test) including colour, smell, appearance, taste, and consistency were performed in jams.

\section{Physicochemical Analysis}

\section{Determination of water-soluble dry matter (Brix)}

Water-soluble dry matter (Brix) was determined at $20^{\circ} \mathrm{C}$ with a refractometer (RA-500 model KEM digital refractometer) as " $\mathrm{g} / 100 \mathrm{~g}$ " (AOAC, 1980).

\section{Determination of pH}

Frozen artichoke and jam samples were mashed and $\mathrm{pH}$ values were determined by measuring at room temperature by using $\mathrm{pH}$ meter (Sevencompact pH/Ion Mettler Toledo) (Cemeroğlu, 2007).

\section{Determination of total acidity}

Jam samples were mashed and total acidity was determined by potentiometric method. Samples were titrated to $\mathrm{pH} 8.1$ with $0.1 \mathrm{~N} \mathrm{NaOH}$ and total acidity values were calculated in $\mathrm{g} / 100 \mathrm{~g}$ citric acid (AOAC, 1996).

\section{Colour determination}

Colour analysis of the artichoke jam samples was carried out using the Konica Minolta CR-5 (Japan) colour analyzer. Hunter $L, a, b$ values were analyzed (Bakirci et al., 2016).

\section{Determination of sugar (Lane-Eynon Method)}

\section{Determination of reducing Sugar}

$5 \mathrm{~g}$ of the sample was weighed and transferred to $250 \mathrm{~mL}$ volumetric flask, and the flask was filled with distilled water to its half-point. $10 \mathrm{~mL}$ of Carrez I and $10 \mathrm{~mL}$ of Carrez II solutions were added thereon for clarification. The flask was filled to its line with distilled water, left for 10 minutes and filtered. Then, the obtained filtrate was filled in a burette. $5 \mathrm{~mL}$ Fehling A and $5 \mathrm{~mL}$ Fehling B solutions were added in an Erlenmeyer and boiled swiftly on high heat. After boiling, 2-3 drops of 1\% methylene blue were added in 2 minutes and titration was performed with the filtrate in the burette. Filtrate consumption was recorded and the amount of degraded sugar was calculated with the associated formula (AOAC, 1984).

\section{Determination of total sugar}

$50 \mathrm{~mL}$ was taken from the filter prepared for determination of invert sugar and transferred to $100 \mathrm{~mL}$ measuring flask. $5 \mathrm{~mL}$ of concentrated $\mathrm{HCl}(37 \%)$ was added and the lid of the flask was sealed and kept in a $67^{\circ} \mathrm{C}$ water bath for 5 minutes. The filtrate removed from the water bath was rapidly cooled under cold water flow and neutralized with $5 \mathrm{~N} \mathrm{NaOH}$. After completed to the level $100 \mathrm{~mL}$ with distilled water, it was used for titration like the invert sugar determination process. Sugar amounts were expressed in g/100 g (AOAC, 1984). 
Determination of HMF

$5 \mathrm{~g}$ of the homogenized test sample was taken and transferred to the $100 \mathrm{~mL}$ labelled measuring flask and $50 \mathrm{~mL}$ of distilled water was added. $2 \mathrm{~mL}$ of Carrez I and Carrez II were added respectively. The measuring flask was diluted to the marked point with distilled water, mixed and filtered. $2 \mathrm{~mL}$ of the test solution was added to each of the four test tubes (A, B, C, and D) by means of a pipette. $5 \mathrm{~mL}$ of p-toluidine reagent was added to each of the tubes, the lids were closed and shaken and rested for 2 minutes. Unlike other tubes, $1 \mathrm{ml}$ of distilled water was added to the content of tube A, and the tube was shaken. The cuvette was filled with this solution. $1 \mathrm{~mL}$ of barbituric acid solution was added to the contents of the tubes $\mathrm{B}, \mathrm{C}$ and $\mathrm{D}$, and the tubes were shaken. Cuvettes were filled with these solutions and the absorbance was measured at $550 \mathrm{~nm}$ against the reference solution (distilled water) within 3-4 minutes after the addition of barbituric acid solution (AOAC, 1983).

\section{Determination of total dry matter}

Approximately 3-5 g of crushed jam samples were added to the nickel containers containing sand + baguette which were counterweighted in drying oven at $65-67^{\circ} \mathrm{C}$ and the processed samples were weighted periodically until they reach fixed weight (Kirk ve Sawyer 1991).

\section{Determination of ascorbic acid}

$10 \mathrm{~g}$ of jam sample was weighed and mixed with $70 \mathrm{~mL}$ of $4 \%$ oxalic acid solution and then filtered. As the control solution, $1 \mathrm{~mL}$ of the oxalic acid solution and $9 \mathrm{~mL}$ of dye solution (2,6-dichlorophenol indophenol) were mixed and spectrophotometer was used to read the transmission values (L1) at $520 \mathrm{~nm}$. The same procedure was applied for $1 \mathrm{~mL}$ of filtrate and $9 \mathrm{~mL}$ of dye solution mixture (L2), as a result, two transmission values were determined and the difference of two values was taken and the amount of ascorbic acid (mg / $100 \mathrm{~g}$ ) was determined (Tamer, 2012).

\section{Antioxidant capacity and total phenolic content analysis}

\section{Extraction for total phenolic content and antioxidant activity analysis}

$20 \mathrm{~mL}$ of extraction solution ( $\mathrm{HCl}$ : methanol: water, 1:80:10) was added on $2 \mathrm{~g}$ of artichoke and artichoke jam samples (Beta et al., 2016; Vitali et al., 2005). Samples were kept in shaking water bath at $20^{\circ} \mathrm{C}$ for 2 hours (Memmert WNB 22). After then, samples were centrifuged at $3500 \mathrm{rpm}$ for 10 min (Sigma 3K30). The supernatants obtained after centrifugation were used for total phenolic content and antioxidant capacity analyzes.

\section{Determination of total phenolic content}

$0.25 \mathrm{~mL}$ extract, $2.3 \mathrm{~mL}$ distilled water and $0.15 \mathrm{~mL}$ Folin-Ciocalteu (FC) reagent (1 unit of FC: prepared using 5 units of distilled water) were used for the analysis. The mixture was then vortexed for 15 seconds. Saturated $\mathrm{Na}_{2} \mathrm{CO}_{3}(35 \%)$ was added thereon and the content of the tube was shaken and kept in dark for 2 hours. After 2 hours, the absorbance of the sample taken from the tube was compared to the blank sample prepared with distilled water at $725 \mathrm{~nm}$ and the result was calculated by means of the formula obtained from prepared gallic acid curve $\left(\mathrm{R}^{2}=0.9835\right)$ as "mg gallic acid equivalent/100g" (Zhang and Hamauzu, 2004).

\section{Determination of antioxidant capacity}

DPPH (2-diphenyl-1-picrylhydrazyl) (Katalinic et al., 2006), FRAP (Ferric Reducing Antioxidant Power) (Benzie and Strain, 1996) and CUPRAC (Copper (II) reducing antioxidant capacity) (Apak et al., 2005) methods were used for the determination of antioxidant capacity. All of the results were given as $\mu$ mol TE (Trolox equivalent)/g in frozen artichoke and artichoke jam by using equation obtained from calibration curves. $\mathrm{R}^{2}$ values of curves were determined as $0.99,0.97$ and 0.99 for DPPH, FRAP and CUPRAC methods, respectively. 
$\mathrm{DPPH}$

3.9 mL DPPH $\left(6 \times 10^{-5} \mathrm{M}\right)$ was added on $0.1 \mathrm{~mL}$ extract and after being kept for 30 minutes in dark, absorbance was performed on $515 \mathrm{~nm}$. For the calibration curve, $0.0256 \mathrm{~g}$ Trolox $\left(1 \times 10^{-3} \mathrm{M}\right)$ was weighed and completed to $100 \mathrm{~mL}$ with pure methanol.

\section{CUPRAC}

$1 \mathrm{~mL}$ of $\mathrm{Cu}$ (II) chloride solution $\left(1 \times 10^{-2} \mathrm{M}\right), 1 \mathrm{~mL}$ of neocuproin alcohol solution $\left(7.5 \times 10^{-3} \mathrm{M}\right)$ and $1 \mathrm{~mL}$ of ammonium acetate solution $(1 \mathrm{M})$ were mixed. $\mathrm{X} \mathrm{mL}$ extract and $(1-\mathrm{x}) \mathrm{mL}$ of distilled water are added thereon. After $30 \mathrm{~min}$, the absorbance values were measured at $450 \mathrm{~nm}$.

\section{FRAP}

In the FRAP method, $3 \mathrm{~mL}$ was taken from daily prepared FRAP solution $(25 \mathrm{~mL} 0.3 \mathrm{~mol} / \mathrm{L}$ acetate buffer solution (pH 3.6), $2.5 \mathrm{~mL} 20 \mathrm{mmol} / \mathrm{L}, \mathrm{Fe}_{3} \mathrm{Cl}$ x $6 \mathrm{H}_{2} \mathrm{O}$ and 2,. $\mathrm{mL} 10 \mathrm{mmol} / \mathrm{L} \mathrm{TPTZ}$ solution) $\left(37^{\circ} \mathrm{C}\right)$ and mixed with $300 \mu \mathrm{L}$ distilled water and $100 \mu \mathrm{L}$ of sample to be tested (or with extraction solution for the control group). Samples to be analyzed and the control sample were placed in a water bath $\left(37^{\circ} \mathrm{C}\right)$ for 60 minutes. At the end of the incubation, reading was carried out at $595 \mathrm{~nm}$ without any delay.

\section{Sensory Analysis}

Hedonic test was applied to determine which jam of the artichoke species used will be preferred the most (Basu and Shivhare, 2011). In the hedonic test conducted with a group of 10 trained-panelists, the products were evaluated in terms of colour, appearance, taste, smell and consistency.

\section{Statistical analysis}

The data obtained in the study were subjected to variant analysis three times in accordance with "Randomized Block Design". LSD test in the level of 5\% probability was used for calculation of the difference between the averages. Calculations were conducted with "JMP 14" statistics software.

\section{Results and Discussion}

\section{Physicochemical Analysis}

The results of the physicochemical analysis of artichoke jams are shown in Table 1 and Table 2. Total dry matter amount was determined between 73.36 and $74.36 \mathrm{~g} / 100 \mathrm{~g}$ in artichoke jams and $14.01 \mathrm{~g} / 100 \mathrm{~g}$ in the raw material. Water-soluble dry matter amounts of jam samples were determined between 69.75 and $70.8 \mathrm{~g} / 100$ g. Water-soluble dry matter of product is generally between $65 \%$ or $68 \%$ with the addition of sugar to prevent microbiological degradation of the product (Basu and Shivhare, 2010). In the Turkish Food Codex (Anonymous, 2006), it is specified that water-soluble dry matter amount determined by means of refractometer in traditional and extra-traditional jams must be minimum $68 \%$ and $\mathrm{pH}$ range must be between 2.8 and 3.5 . The total acidity values of artichoke jams were found to be between 0.08 and $0.11 \mathrm{~g} / 100 \mathrm{~mL}$, and the $\mathrm{pH}$ values were found to be between 3.40 and 3.81. The reason for the $\mathrm{pH}$ value determined in the study to be different from the Turkish Food Codex is the fact that acidity of the artichoke plant was low compared to many other plants.

Ascorbic acid values of the jams were found to be 1.42 and $4.07 \mathrm{mg} / 100 \mathrm{~g}$. Ascorbic acid content and the rate of exposure to heat treatment may vary depending on the variety of artichoke. In frozen artichoke, the ascorbic acid value was detected as $11.98 \mathrm{mg} / 100 \mathrm{~g}$ and compared to this ascorbic acid content of the jams was determined significantly low. It is known that loss of ascorbic acid occurs in heat treatment processes. In a study conducted by Jawaheer et al. (2003), stated that after the jam-making process, the ascorbic acid content of guava fruit reduced by $39 \%$. Even though the raw materials used in these two studies are different, this can 
be associated with the fact that ascorbic acid is the vitamin that is the most prone to oxidation and that oxidation speed increases directly proportional to ambient temperature (Dauthy, 1995).

Table 1: Physicochemical properties of artichoke jam samples

\begin{tabular}{|c|c|c|c|c|}
\hline & $\bar{I}$ & BP & $\mathrm{S}$ & $\mathrm{DE}$ \\
\hline Total dry matter $(\mathrm{g} / 100 \mathrm{~g})$ & $74.36 \pm 0.44^{\mathrm{a}}$ & $74.19 \pm 1.78^{\mathrm{a}}$ & $73.36 \pm 0.09^{\mathrm{a}}$ & $14.01 \pm 0.99^{\mathrm{b}}$ \\
\hline Water soluble dry matter $(\mathrm{g} / 100 \mathrm{~g})$ & $69.75 \pm 0.25^{b}$ & $70.8 \pm 0.3^{\mathrm{a}}$ & $69.92 \pm 0.22^{\mathrm{b}}$ & \\
\hline Total acidity $(\mathrm{g} / 100 \mathrm{~g})^{*}$ & $0.09 \pm 0.00^{\mathrm{b}}$ & $0.08 \pm 0.00^{\mathrm{a}}$ & $0.11 \pm 0.01^{\mathrm{b}}$ & $0.05 \pm 0.00^{\mathrm{d}}$ \\
\hline $\mathrm{pH}$ & $3.40 \pm 0.02^{\mathrm{b}}$ & $3.49 \pm 0.23^{\mathrm{a}}$ & $3.81 \pm 0,12^{\mathrm{c}}$ & $4.66 \pm 0.01^{\mathrm{a}}$ \\
\hline Ascorbic acid (mg/100 g) & $4.07 \pm 0.15^{\mathrm{b}}$ & $1.42 \pm 0.55^{\mathrm{c}}$ & $4.07 \pm 0.25^{\mathrm{b}}$ & $11.98 \pm 0.36^{\mathrm{a}}$ \\
\hline \multicolumn{5}{|l|}{ Colour } \\
\hline$L$ & $30.88 \pm 0.22^{\mathrm{b}}$ & $22.48 \pm 0.02^{\mathrm{c}}$ & $27.24 \pm 0.69^{\mathrm{bc}}$ & $64.9 \pm 4,82^{\mathrm{a}}$ \\
\hline$a$ & $7.18 \pm 0.10^{\mathrm{c}}$ & $10.93 \pm 0.11^{\mathrm{a}}$ & $9.78 \pm 0.42^{b}$ & $0.41 \pm 0.04^{\mathrm{d}}$ \\
\hline$b$ & $26.89 \pm 0.00^{\mathrm{a}}$ & $26.55 \pm 0.00^{\mathrm{a}}$ & $23.69 \pm 0.17^{b}$ & $24.13 \pm 0.63^{b}$ \\
\hline $\mathrm{HMF}(\mathrm{mg} / \mathrm{kg})$ & $51.79 \pm 0.32^{b}$ & $36.09 \pm 6.95^{\mathrm{b}}$ & $39.97 \pm 1.17^{\mathrm{a}}$ & \\
\hline \multicolumn{5}{|l|}{ Sugar } \\
\hline Total sugar $(\mathrm{g} / 100 \mathrm{~g})$ & 69.92 & 63.17 & 59.51 & \\
\hline Reducing sugar $(\mathrm{g} / 100 \mathrm{~g})$ & 35.84 & 43.69 & 15.75 & \\
\hline
\end{tabular}

I: Artichoke jam made from imported artichoke, BP: Sample of artichoke jam produced from Bayrampaşa artichoke, S: Sample of artichoke jam produced from Sakız artichoke the samples shown in different letters in the same row are statistically different $(\mathrm{p}<0.01)$

One of the most important characteristics that determine the visual quality of food products is colour. The $L, a$, and $b$ values of the artichoke jams used in the study are provided in Table 1 . Significant changes in the original fruit colour can occur during the production processes in jams (Igual et al., 2014). It was determined that $L$ value, which is an indicator of light and consistency, was 64.9 in frozen artichokes and it was found that it decreased in average $41.40 \%$ in jam samples compared to frozen artichokes. The decrease in $L$ indicates that consistency is decreased. It was determined that $a$ value, which expresses redness (+) and greenness (-), increased by 26 times by processing the artichoke into jam. Increase in $a$ value could be caused by nonenzymatic browning reactions and other ingredients in jam samples such as cinnamon sticks and cloves. $b$ values of yellowness (+) and blueness (-) were found to be 24.13 on frozen artichokes and no significant change was observed when compared to jam samples $(\mathrm{p}<0.01)$. In particular, the decrease in $L$ value is caused by the heat treatment applied during the jam processing causing browning. In addition, preparation and the openkettle process could cause oxidation and degradation of colour pigments and this may cause changes in colour values during jam production.

HMF is an important quality index in jams. High and long heat treatment and high storage temperature are the main reason of HMF in jams. High HMF content gives off and burnt flavour, which causes a negative effect on consumer's preference. In the study, HMF amounts of artichoke jam were found to be between 36.09 and $51.79 \mathrm{mg} / 100 \mathrm{~g}$. In the literature, it was suggested that the amount of HMF should not exceed $50 \mathrm{mg} / \mathrm{kg}$ in first-grade jams and $100 \mathrm{mg} / \mathrm{kg}$ in second-grade jams (Gülpek and Başoğlu, 1989; Bilişli, 1998) and the values determined in our study is in line with the literature.

The total sugar content of artichoke jams was found to be 59.51 and $69.92 \mathrm{~g} / 100 \mathrm{~g}$ and reducing sugar amounts were within the range of 15.75 and $43.69 \mathrm{~g} / 100 \mathrm{~g}$. The time of heat treatment applied during cooking of the jam samples varied in each sample until the desired amount of water-soluble dry matter. Since the increase in reducing sugar ratio depends on the $\mathrm{pH}$ value, heating temperature and duration (Güzel and Mercan, 
2004), the reducing sugar content of jam samples varied considerably. Sahu (2016) reported that the total sugar values in the jams produced from Aonla Fruit (Emblica Officinalis Syn.) ranged between 50.51 and $51.96 \mathrm{~g} / 100$ $\mathrm{g}$ and reducing sugar values were between 42.07 and $43.50 \mathrm{~g} / 100 \mathrm{~g}$. According to Cemeroğlu \& Acar (1986), in order to prevent the crystallization in jams, the proportion of reducing sugar should be between $3-43 \%$ for jams with a total dry matter ratio of $65 \%$. The results obtained were consistent with the previous studies.

Table 2: Antioxidant capacity and total phenolic content of frozen artichoke and artichoke jam samples

\begin{tabular}{ccccc}
\hline & I & S & BP & DE \\
\hline $\begin{array}{c}\text { Antioxidant Capacity }(\mu \mathrm{mol} \\
\text { TE*/g dw) }\end{array}$ & & & \\
\hline DPPH & $7.67 \pm 0.03^{\mathrm{b}}$ & $7.41 \pm 0.40^{\mathrm{b}}$ & $7.61 \pm 0.10^{\mathrm{b}}$ & $38.92 \pm 0.10^{\mathrm{a}}$ \\
CUPRAC & $10.21 \pm 0.06^{\mathrm{c}}$ & $12.86 \pm 0.82^{\mathrm{c}}$ & $22.99 \pm 1.62^{\mathrm{b}}$ & $110.78 \pm 3.54^{\mathrm{a}}$ \\
FRAP & $6.47 \pm 0.08^{\mathrm{c}}$ & $8.05 \pm 0.98^{\mathrm{c}}$ & $14.12 \pm 1.38^{\mathrm{b}}$ & $79.29 \pm 9.09^{\mathrm{a}}$ \\
Total Phenolic Content (mg & $142.09 \pm 18.21^{\mathrm{b}}$ & $145.37 \pm 5.64^{\mathrm{b}}$ & $183.39 \pm 4.06^{\mathrm{b}}$ & $814.70 \pm 58.98^{\mathrm{a}}$ \\
GAE**/ 100 g) & & & \\
$* \mu$ mol TE (Trolox equivalent) /g dw (dry weight) **GAE: Gallic acid equivalent, Samples shown in different letters in the same row are &
\end{tabular}

I: Artichoke jam made from imported artichoke, BP: Sample of artichoke jam produced from Bayrampaşa artichoke, S: Sample of artichoke jam produced from Sakız artichoke, DE: Frozen Artichoke Heart

The antioxidants neutralize the free radicals that appear as secondary metabolites in the human body and prevent the negative effects caused by these molecules. The human body has various mechanisms to prevent damage to the cellular size caused by free radicals due to the high antioxidant containing nutrients (Oroian and Escriche, 2015).

The antioxidant capacity of frozen artichoke used as raw material was calculated as $38.92 \mu \mathrm{mol}$ Trolox/g dry weight with DPPH method. As a result of the analysis conducted with DPPH method, Rouphael et al. (2016) reported that antioxidant capacity of fresh artichoke heart was changed between 10.9 and 22.6 $\mu \mathrm{mol}$ Trolox/ $100 \mathrm{~g}$ dry weight. When the results obtained in our study and the values obtained from the literature were compared, it was observed that the raw material used in jam-making had higher antioxidant capacity. The reason for this situation can be explained by the fact that the growing regions and variety of the artichoke heads analyzed are different and processes after the harvest may vary.

When antioxidant capacities of artichoke jams were evaluated according to the DPPH method, it was determined that the sample I had the highest antioxidant capacity with $7.67 \mu$ mol Trolox / g dry weight. It was determined that this sample was followed by BP and S samples with 7.61 and $7.41 \mu \mathrm{mol}$ TE/g DW values respectively. In a study conducted by Lutz et al. (2011) antioxidant capacity was measured after cooking a mature artichoke heart. They determined the \% inhibition value of mature and cooked artichoke hearts is reported as 34.56 with DPPH method.

The antioxidant capacity determined by the CUPRAC method in frozen artichoke was found to be $110.78 \mu \mathrm{mol} \mathrm{TE} / \mathrm{g} \mathrm{dw}$. Antioxidant capacity values of I, S and BP varieties were determined as 10.21, 12.86 and $22.99 \mu \mathrm{mol} \mathrm{TE} / \mathrm{g} \mathrm{dw}$ respectively. In comparison, the frozen artichoke sample had a high antioxidant capacity, while jam samples had lower. BP sample was observed to have a higher antioxidant value compared to the other two samples.

In the analysis using the FRAP method, the antioxidant capacity value of the frozen artichoke heart was $79.29 \mu \mathrm{mol} \mathrm{TE} / \mathrm{g} \mathrm{dw}$. In the same method, it was observed that the BP sample had the highest antioxidant capacity with $14.12 \mu \mathrm{mol} \mathrm{TE} / \mathrm{g}$ dw followed by $\mathrm{S}$ and I samples with 8.05 and $6.47 \mu \mathrm{mol} \mathrm{TE} / \mathrm{g}$ dw respectively. In a study where Jiménez-Escrig et al. (2003) determined the antioxidant capacity in lyophilized artichoke heart samples with FRAP method, as $235 \mu \mathrm{mol} \mathrm{TE} / \mathrm{g}$ dw. A clear difference can be seen between the values 

determined in this study and the literature. The reason might be explained by the difference between the varieties of artichokes used and the jam-making processes.

In the comparisons made by DPPH, FRAP and CUPRAC methods, a significant decrease around 8090\% in antioxidant content was detected in artichoke jams from raw material. A study conducted on the antioxidant activity of 6 cultivars of raspberry and blackberry showed that $73.42-95.16 \%$ decrease in antioxidant activity between raw materials and jam samples (Tamer, 2011). Natural polyphenols included in the structure of the raw material deteriorate because of the heat treatment applied during jam production. Moreover, complex reactions of lipid oxidation products, ascorbic acid and polyphenolic components cause a reduction of antioxidant activity during both processing and storage (Frankel, 2007).

The total phenolic content of the frozen artichoke heart was found as $814.70 \mathrm{mg}$ GAE/100 g dry weight. It was observed that the total phenolic component content was quite low in artichoke jams compared to the frozen artichokes. The decrease of total phenolic content was determined between $75-82 \%$ in total phenolic content from raw material to jam. The BP sample had the highest total phenolic content with 183.39 mg GAE/100 g dry weight value. S and I samples were found as close to each other with 145.37 and 142.09 mg GAE/100 g dry weight values, respectively. In a study, the total phenolic content of black carrot jam was analyzed; a reduced rate compared to raw material was 89.2 to $90.5 \%$. It was explained by the fact that the heat treatment applied during jam production caused deterioration in cellular structure and the raw material becomes prone to non-enzymatic oxidation (Kamiloglu et al., 2015).

\section{Sensory Analysis}

The results of the sensory analysis of artichoke jams produced using the same formulation from three different artichoke varieties are given in Table 3 . As a result of the sensory analysis, it was determined that colour, appearance, and consistency characteristics of jam samples are statistically significant and smell and taste characteristics were statistically non-significant. The sample I was found to have the highest average value in terms of colour and appearance and was found much desirable than other samples. In terms of consistency, the BP sample was found desirable much more than other jam samples. The overall acceptability values of the jam samples were changed between the range of 3.6-4.5 and the most preferred jam sample was found to be I with an average of 4.5 .

Table 3: Sensory analysis of artichoke jam

\begin{tabular}{ccccccc} 
Jam Sample & Colour & Appearance & Odour & Taste & Consistency & $\begin{array}{c}\text { Overall } \\
\text { Acceptability }\end{array}$ \\
\hline S & $3.30 \pm 0.82^{\mathrm{ab}}$ & $3.20 \pm 1.03^{\mathrm{b}}$ & $4.00 \pm 0.67^{\mathrm{ns}}$ & $4.20 \pm 0.63^{\mathrm{ns}}$ & $3.10 \pm 0.88^{\mathrm{b}}$ & $3.60 \pm 0.70^{\mathrm{b}}$ \\
BP & $2.90 \pm 0.89^{\mathrm{b}}$ & $3.60 \pm 1.07^{\mathrm{ab}}$ & $4.20 \pm 0.57^{\mathrm{ns}}$ & $4.20 \pm 0.92^{\mathrm{ns}}$ & $4.10 \pm 0.57^{\mathrm{a}}$ & $4.00 \pm 0.47^{\mathrm{ab}}$ \\
I & $4.10 \pm 0.87^{\mathrm{a}}$ & $4.30 \pm 0.68^{\mathrm{a}}$ & $4.10 \pm 0.99^{\mathrm{ns}}$ & $4.50 \pm 0.71^{\mathrm{ns}}$ & $3.7 \pm 0.82^{\mathrm{ab}}$ & $4.50 \pm 0.97^{\mathrm{a}}$ \\
\hline
\end{tabular}

Samples shown in different letters in the same column are statistically different $(\mathrm{p}<0.01)$ I: Artichoke jam made from imported artichoke, BP: Sample of artichoke jam produced from Bayrampaşa artichoke, S: Sample of artichoke jam produced from Sakız artichoke, DE: Frozen Artichoke Heart

\section{Conclusion}

The jam making process is one of the alternative methods to extend the self-life of artichokes in terms of physicochemical and microbiological. The ascorbic acid content in jams was observed to decrease compared to raw material. The highest reduction was observed in Bayrampaşa, while Sakız and Imported preserved ascorbic acid content compared to fresh artichoke.

According to CUPRAC and FRAP assays, the highest antioxidant capacity, as well as total phenolic content, was observed in jam samples produced from Bayrampaşa cultivar. Also, statistical analyzes of sensorial acceptability showed that it was preferred in terms of consistency more than other samples. The imported artichoke was preferred in terms of colour, appearance and overall acceptability. According to nutritional value and consumer preferences, it is suitable to apply the jam-making process to artichoke. 


\section{References}

Anonymous. 2006. Turkish Food Codex - Regulations for jams, jellies, marmalades and sweetened chestnut purée. Official Gazette 26392.

Association of Analytical Communities - AOAC. 1980. Solids (soluble) in fruits and fruit products: 932.12. Rockville: AOAC International.

Association of Analytical Communities - AOAC. 1996. Solids (soluble) in fruits and fruit products: 962.19. Rockville: AOAC International.

Association of Analytical Communities - AOAC. 1984. Official methods of analysis: sugar and sugar products: 968.28. Rockville: AOAC International.

Association of Analytical Communities - AOAC. 1983. Official methods of analysis: HMF in honey, Spectrophotometric method: 980.23. Rockville: AOAC International.

Apak, R., Güçlü, K., Özyürek, M., Karademir, S.E., \& Altun, M. 2005. Total antioxidant capacity assay of human serum using copper (II)neocuproine as chromogenic oxidant: The CUPRAC method. Free Radical Research 39: 949-961.

Bakirci, S., Dagdemir, E., Boran, O.S., \& Hayaloglu, A.A. 2016. The effect of pumpkin fibre on quality and storage stability of reduced-fat set-type yoğurt. International Journal of Food Science \& Technology 52:180-187.

Basu, S., and Shivhare, U.S. 2010. Rheological, textural, microstructural and sensory properties of mango jam. Journal of Food Engineering 100:357-365.

Basu, S., Shivhare, U.S., Singh, T.V., \& Beniwal, V.S. 2011. Rheological, textural and spectral characteristics of sorbitol substituted mango jam. Journal of Food Engineering 105:503-512.

Beta, T., Nam, S., Dexter, J.E., \& Sapirstein, H.D. 2005. Phenolic content and antioxidant activity of pearled wheat and roller-milled fractions. Cereal Chemistry 82:390-393.

Benzie, I.F.F., \& Strain, J.J. 1996. The ferric reducing ability of plasma (FRAP) as a measure of "antioxidant power": The FRAP assay. Analytical Biochemistry 239:70-76.

Bilişli, A. 1998. Reçel ve Benzeri Ürünler Teknolojisi. Tav Yayınları, Yalova.

Cemeroğlu, B., \& Acar, J. 1986. Meyve ve Sebze İşleme Teknolojisi. Gıda Teknolojisi Derneği Yayın No:6, Sanem Matbacılık, Ankara.

Cemeroğlu, B., Yemenicioğlu, A., Özkan, M. 2001. Meyve ve Sebzelerin Bileşimi. Soğukta Depolanmaları (1). Gıda, 24(3):21-25.

Cemeroğlu, B. 2007. Gıda Analizleri. Gıda Teknolojisi Derneği Yayınları, No: 34, Ankara.

Ciancolini, A., Alignan, M., Pagnotta, M.A., Miquel, J., Vilarem, G., \& Crino, P. 2013. Morphological characterization, biomass and pharmaceutical compounds in Italian globe artichoke genotypes. Industrial Crops and Products 49: 326-333.

Dauthy, M.E. 1995. Fruit and Vegetable Processing. Food and Agriculture Organization of the United Nations, Rome.

Eser, B. 2002. Enginar Yetiştiriciliği. Retrieved from: www.agr.ege.edu.tr [15.07.2019]

Frankel, E.N. 2007. Antioxidants in Food and Biology, Facts and Fiction. The Oily Press, Bridgwater.

Gülpek, N., \& Basoglu, F. 1989. Taze ve dondurularak muhafaza edilmis çilek kullanılarak yapılan reçellerin kalitesi üzerine bir araştırma. Glda 14:121-128. Retrieved from: http://dergipark.org.tr/gida/issue/6875/92053 [15.07.2019]

Güzel, Y.M., \& Mercan, T. 2004. Farklı Reçeteler Kullanılarak Üretilen Çilek Reçellerindeki Hidroksimetilfurfural (HMF) Oluşumu ve Depolama Süresindeki Değişimi. Gıda ve Yem Bilimi Teknolojisi 6:1-7.

Igual, M., Contreras, C., \& Martinez-Navarrete, N. 2014. Colour and rheological properties of non-conventional grapefruit jams: Instrumental and sensory measurement. LWT-Food Science and Technology 56:200-206.

Jawaheer, B., Goburdhun, D., \& Ruggoo, A. 2003. Effect of Processing and Storage of Guava Into Jam and Juice on the Ascorbic Acid Content. Plant Foods for Human Nutrition 58:1-12

Jimènez-Escrig, A., Dragsted, L.O., Daneshvar, B., Pulido, R., \& Saura-Clixto, F. 2003. In Vitro Antioxidant Activities of Edible Artichoke (Cynara scolymus L.) and Effect on Biomarkers of Antioxidants in Rats. Journal of Agricultural and Food Chemistry 51:5540-5545.

Kamiloglu, S., Pasli, A.A., Ozcelik, B., Van Camp, J., \& Capanoglu, E. 2015. Influence of different processing and storage conditions on in vitro bioaccessibility of polyphenols in black carrot jams and marmalades. Food Chemistry 186: 74-82.

Katalinic, V., Milos, M., Kulisic, T., \& Jukic, M. 2006. Screening of 70 medicinal plant extracts for antioxidant capacity and total phenols. Food Chemistry 94: 550-557.

Kim, D.P., \& Padilla-Zakour, O.I. 2004. Jam Processing Effect on Phenolics and Antioxidant Capacity in Anthocyanin-rich Fruits: Cherry, Plum, and Raspberry. Sensory and Nutritive Qualities of Food 69: 395-400.

Kirk, S., \& Sawyer, R. 1991. Pearson's composition and analysis of foods. Teddington, Middlesex. 
Durmus \&Ozcan-Sinir\& Sahin \&Çopur Determination of physicochemical properties and antioxidant capacity of artichoke (Cynara carduncuus var Scolymus L.) jam produced from different cultivars Lattanzio, V., Kroon, P.A., Linsalata, V. \& Cardinali, A. 2009. Globe artichoke: A functional food and source of nutraceutical ingredients. Journal of Functional Foods 1:131-144.

Lutz, M., Henriquez, C. \& Escobar, M. 2011. Chemical composition and antioxidant properties of mature and baby artichokes (Cynara scolymus L.), raw and cooked. Journal of Food Composition and Analysis. 24:49-54.

Muratore, G., Restuccia, C., Licciardello, F., Lombardo, S., Pandino, G. \& Mauromicale, G. 2015. Effect of packaging film and anti-browning solution on quality maintenance of minimally processed globe artichoke heads. Innov Food Sci Emerg Technol 31:97-104.

Oroian, M. \& Escriche, I. 2015. Antioxidants: Characterization, natural sources, extraction and analysis. Food Research International 74:1036.

Rouphael, Y., Bernardi, J., Cardarelli, M., Bernardo, L., Kane, D., Colla, G. \& Lucini, L. 2016. Phenolic Compounds and Sesquiterpene Lactones Profile in Leaves of Nineteen Artichoke Cultivars. Journal of Agricultural and Food Chemistry 64:8540-8548.

Sahu, G. 2016. Studies on utilization of aonla fruit (Emblica Officinalis Syn.) for preparation of jam and preservation of aonla fruit products. Journal of Agriculture and Technology 3:48-55.

Shinvari, K.J. \& Rao, P.S. 2018. Stability of bioactive compounds in fruit jam and jelly during processing and storage: A review. Trends in Food Science and Technology 75:181-193.

Tamer, C.E. 2012. A research on raspberry and blackberry marmalades produced from different cultivars. Journal of Food Processing and Preservation 36:74-80.

Vitali, D., Vedrina Dragojevic, I., \& Sebecic, B. 2009. Effects of incorporation of integral raw materials and dietary fibre on the selected nutritional and functional properties of biscuits. Food Chemistry 114: 1462-1469.

Wang, M.F., Simon, J.E., Aviles, I.F., He, K., Zheng, Q.Y., \& Tadmor, Y. 2003. Analysis of antioxidative phenolic compounds in artichoke (Cynara scolymus L.). Journal of Agricultural and Food Chemistry 51:601-608.

Wolf, B. (2016). Confectionery and Sugar-Based Foods. [Online]. Reference Module in Food Science. Retrieved from: https://www.sciencedirect.com/science/article/pii/B9780081005965034521 [15.07.2019].

Zhang, D., \& Hamauzu, Y. 2004. Phenolics, ascorbic acid, carotenoids and antioxidant activity of broccoli and their changes during conventional and microwave cooking. Food Chemistry 88: 503-509. 